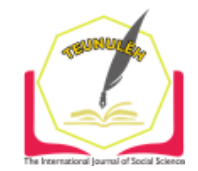

Jurnal Ilmiah Teunuleh

The International Journal of Social Sciences

Vol. 1, Issue. 1, Sept 2020

E-ISSN: $2746-4393$

\title{
IMPROVEMENT OF LEARNING INTEREST THROUGH POWERPOINT ON THE NATURAL IMPACT MATERIALS OF CLASS IV STATE SD PASI PINANG
}

\author{
Yulia Maulida \\ STKIP Bina Bangsa Meulaboh, Indonesia \\ Email:yuliamaulida19@gmail.com
}

\begin{abstract}
The purpose of this study was to determine the increase in interest in learning by using PowerPoint media on natural appearance material in grade IV SD Negeri Pasi Pinang, Meureubo District, West Aceh. The research approach used is qualitative research with the type of research used is a classroom action research research subject totaling 12 grade IV students with 6 male students and 6 female students. Before the researcher took action, the observation results obtained in the pre-cycle got an average of $38.29 \%$. After the researcher conducted the research and obtained the data, then the researcher processed the observation data on the interest in learning and the questionnaire on the student's interest in learning in the first cycle based on the results of the observation that the average percentage was $54.16 \%$ while the questionnaire results obtained a score of 2.06 and in the second cycle the observation results obtained an average of $88.75 \%$, the results of the questionnaire obtained a score of 3.30. When the learning process takes place using PowerPoint media, students' attention is very big in learning when the teacher explains material about natural appearances. This shows that with the PowerPoint media the students' interest in learning has increased more than before in the material appearance of the fourth grade students of SD Negeri Pasi Pinang, Meureubo District, West Aceh.
\end{abstract}

Keywords: PowerPoint Media, Learning Interests, Social Studies, Natural Appearances.

\section{A. Introduction}

Education with the rapid development of science and technology today will have an impact on progress in various fields of life. In order to follow and improve the development of science and technology, qualified human resources are needed. One of the efforts to create quality human resources is through education. The advancement of 
technology and information also triggers changes in the learning system, namely efforts to separate the world of education from conventional learning models.

Education is a very decisive field, because education itself functions to develop attitudes and abilities and improve the quality of life and human dignity. Learning is basically an activity carried out by the teacher aimed at students by carrying out activities to educate, teach, train and guide students so that learning achievement is good, which is shown by mastering the learning material by students who are declared with values. The learning process can occur anytime and anywhere. The learning process occurs because of the interaction of individuals with their environment. One of the signs that someone has learned is a change in him. Changes in question are changes that are knowledge (cognitive), skills (psychomotor), changes in values and attitudes (affective). The success or failure of this education depends on how the teacher educates his students.

In the teaching and learning process, the teacher as a facilitator is obliged to develop learning materials in order to provide the learning outcomes that you want to achieve. To achieve this goal, learning media is needed that can be used to improve students' ability to learn easily, so that the material provided can be understood by students. The use of learning media is very important. Because the media as a tool to convey information. Without learning media, learning objectives will not be maximally achieved so that student learning outcomes are not what the teacher wants. The use of instructional media in the teaching and learning process can arouse the enthusiasm for learning, even have an influence on students, and also greatly help the effectiveness of the learning process, the delivery of messages and lesson definitions at that time. Student learning outcomes are abilities that children acquire after going through learning activities.

Currently, there are various learning media available, ranging from simple media to high-tech media. Therefore, teachers need to have the ability to utilize learning media so that learning objectives can be achieved more effectively and efficiently. Teachers need to have knowledge and use various available learning media.

Interest is the tendency to be attracted to something relatively fixed to pay more attention and to remember continuously followed by a sense of pleasure to obtain a satisfaction in achieving goals. One way to foster student interest in learning is to use media or props, given that the function of the media is to increase the acceptance of information. In addition, the benefits that can be obtained from learning using 
Improvement of Learning Interest Through Powerpoint on the Natural Impact Materials of...

PowerPoint are that the learning process is more interesting, the amount of teaching time can be more effective, the attitudes and attention of students can be improved and focused. Media can increase the interest and attention of students to learn so that learning outcomes can be achieved. In addition to arousing student interest, learning media can help students improve understanding, and teachers can present lessons in an interesting manner. Learning media are facilities and infrastructure that are used as tools and materials for activities in the learning process.

Based on the results of observations at SD Negeri Pasi Pinang, Meureubo District, West Aceh Regency on January 24, 2017, students' interest in learning was still lacking, it was known that when the learning process took place the social studies interest in grade IV according to research was a little boring for students and tended to lack understanding. It can be seen that when the teacher explains the lesson there are still many students who fight, play in class and pay less attention when the teacher explains the lesson. The reality that occurs in grade IV SD Negeri Pasi Pinang, Meureubo District, West Aceh Regency, when learning takes place in the classroom, teachers tend to be more active (teacher- centered) using conventional methods, namely teachers often lecture and less use learning media. Students only take notes, listen to, and do exercises so that students are less interested in learning.

From the above problems, it can be concluded that every student can easily get bored and bored when the learning process is carried out with full demands and will greatly affect their interest in learning, so they are not interested in learning and do not listen to the teacher's explanation. Based on the observations made by the researcher on the fourth grade students of SD Negeri Pasi Pinang, Meureubo District, West Aceh Regency, especially in social studies there are still students who are not interested in learning, this is the basis for the writer to find solutions in increasing student interest in learning. Therefore, the authors want to apply learning media that is fun and interesting.

Because the simple pictures and information described on the blackboard have not been able to produce a good understanding, there is a need for media in social studies subjects on the subject of natural appearance. The development of science and technology advances renewal efforts in the use of technology in the learning process. In line with that, computers have become popular in their role as learning aids. The application of computers as a learning medium can be seen as the right solution to realizing learning goals, which provide opportunities for students to learn independently. Based on the description above, the researcher is interested in conducting classroom 
action research with the title "Increasing Student Interest in Learning through PowerPoint Media on the Natural Appearance of Class IV Students of SD Negeri Pasi Pinang, Meureubo District, West Aceh Regency".

\section{B. Method}

This research is a type of classroom action research (CAR), which is a study conducted with the aim of improving the quality of the learning process for a group of students. The research was conducted to increase students' interest in learning by applying PowerPoint media in social studies learning with natural appearance material, thus the data to be collected in this study is descriptive in nature, which describes descriptions of student learning activities during the research process.

This research was conducted at SD Negeri Pasi Pinang, Meureubo District, West Aceh Regency. The research implementation took place from June to August 2017. The subjects in this study were all the number of fourth grade students of SD Negeri Pasi Pinang, Meureubo District, 2017/2018 academic year. The number of research subjects was as many as 12 students consisting of 6 male students and 6 female students. The object of this research is the learning interest of fourth grade students of SD Negeri Pasi Pinang, Meureubo District. The flow of Classroom Action research (CAR) can be seen in the following chart:

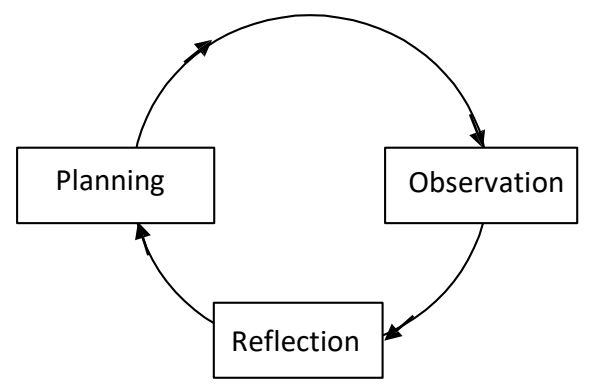

Figure 1. Classroom Action Research Cycle Chart

Research procedure, each cycle there are four stages, namely, planning, action, observation and reflection. The stages are arranged in cycles and the cycle is carried out in accordance with the changes to be achieved.

The data collection techniques in this study, the authors used several techniques to collect data according to the problem. The techniques used in data collection are: Observation, is a data collection technique to conduct direct field observations. In this 
Improvement of Learning Interest Through Powerpoint on the Natural Impact Materials of...

study, researchers made observations of students' interest in learning at SD Pasi Pinang, Meureubo District. So to determine student success, the formula is used:

$$
\text { student scores }=\frac{\text { the number of scores obtained by students }}{\text { the maximum score for all aspects }} \times 100 \%
$$

\section{Finding and Discussion}

\section{Finding}

In processing data on increasing interest in learning through PowerPoint media on the material appearance of the fourth grade students of SD Negeri Pasi Pinang, Meureubo District, West Aceh, which was carried out for $2 \times 35$ minutes with several steps. The first step is to make a questionnaire of 10 questions, the second step is to fill out the student observation sheets carried out by the observer.

The implementation of pre-action activities in this study was carried out by collecting data that had been collected by researchers related to the learning media used to see the interest in learning social studies material on natural appearance in grade IV SD Negeri Pasi Pinang. The results of pre-action observations of the level of interest in learning of fourth grade students of SD Negeri Pasi Pinang before it was held.

From the data obtained, students only seem to tend to ask the teacher if they cannot answer the questions given. The results of observations in the pre- cycle indicators of student interest in learning, namely students feel happy when the teacher enters the class giving lessons totaling 17 (35.41\%), students answer questions given by the teacher totaling 19 (39.58\%), students do not speak alone when the teacher teaches amounted to 17 (35.41\%), students always come to the front of the class if asked by the teacher, amounting to 18 (37.5\%), students are not sleepy when the teacher is explaining lessons totaling 17 (35.41\%), students feel happy when the teacher gives assignments exercises amounted to 16 (33.33\%), students asked the teacher if they could not answer the questions amounted to 20 (41.66\%). Based on the results of observations of students 'interest in learning at SD Pasi Pinang, Meureubo District, West Aceh Regency, in the pre-cycle, the students' interest in learning was low or low.

The implementation of cycle I was carried out on July 29, 2017. In the teaching process of cycle I, researchers carried out learning using PowerPoint media without effects, animations, and videos in accordance with the learning steps that had been compiled, namely in the form of a Learning Implementation Plan (RPP). 
After developing the plan, the research is ready to carry out research by applying PowerPoint media with natural appearance material discussion. In the initial activity the teacher gave greetings, asked the students to pray to give motivation and explain the objectives of the teaching at this first meeting. In the core activity, the teacher explains about natural appearances, the teacher assigns students to mention what they know about natural appearances, the teacher shows PowerPoint about the material in question without using animation. The teacher and students do the question and answer and students are assigned to fill out the questionnaire that has been provided. In the closing stage of learning the teacher concludes the learning outcomes, provides a moral message and ends with greetings.

The results of observations of student activities during learning using PowerPoint media in Cycle I of the 10 indicators of student interest in learning, namely students feel happy when the teacher enters the class giving lessons totaling 23 (47.91\%), students answer questions given by the teacher totaling 24 (50\%), students do not speak for themselves when the teacher teaches 22 (45.83\%), students like the pictures shown in PowerPoint when the teacher teaches 29 (60.41\%), students always come to the front of the class if the teacher asks to be $20(41,66 \%)$, students are happy if the teacher teaches using PowerPoint totaling 29 (60.41\%), students are not sleepy when the teacher is explaining the lesson totals 18 (37.5\%), students are happy when the teacher gives 22 exercises $(45,83 \%)$, students do not play alone when the teacher teaches 23 (47.91\%), students ask the teacher if they cannot answer questions totaling 25 (52.83\%). These results indicate that in carrying out their activities only 1 student is in the good learning interest category, 3 students get enough interest category, and 8 other students get the poor learning interest category. Based on the results of observations of students 'interest in learning at SD Negeri Pasi Pinang, Meureubo District, West Aceh Regency, in the first cycle it was still in the category of students' lack of interest in learning.

Based on the results of the first cycle questionnaire that has been presented in the table above, that the application of PowerPoint media to increase interest in social studies learning in fourth grade students of SD Negeri Pasi Pinang, Meureubo District has not been maximally applied, because it can be seen from a number of questions taken that indicate there are still students who are not Happy when the teacher enters the class giving lessons, still embarrassed to move forward, less happy when the teacher gives assignments, and students are still embarrassed to ask 
Improvement of Learning Interest Through Powerpoint on the Natural Impact Materials of...

questions, so that the average questionnaire score is 2.06 and is in the enough category. Therefore it is necessary to make improvements in the next cycle.

In the first cycle of learning, the application of PowerPoint media has started to run, although it has not been implemented properly. This can be seen in some of the things that are of interest in the observation getting an average of $54.16 \%$ and it is still included in the category of sufficient and insufficient student interest in learning, the results of the questionnaire on learning interest an average of 2.06 percentage of students' desire to learn. Therefore it is necessary to make improvements in the next cycle. The advantages that have been achieved in cycle I are as follows: (a) students are less happy when the teacher enters the class giving lessons, (b) students like to talk to themselves in learning, (c) students are still shy to move forward if told by the teacher, (d) ) there are still students who are embarrassed to ask questions, (e) students do not like it when the teacher gives assignments.

Cycle II, the implementation of cycle II learning was carried out on August 18, 2017. In the second cycle of the teaching process, researchers carried out learning using PowerPoint media using effects, animation and video, in accordance with the learning steps that had been arranged, namely in the form of a Learning Implementation Plan (RPP).

After developing the plan, the researcher is ready to carry out research by applying PowerPoint media with a discussion of natural features. In the initial activity the teacher gave greetings, asked the students to pray to give motivation and explain the objectives of the teaching at this first meeting. In the teacher's core activity of explaining natural features, the teacher assigns students to mention what they know about natural appearances, the teacher pays attention to PowerPoint about the material concerned by using animation and video effects. The teacher and students do the question and answer and students are assigned to fill out the questionnaire that has been provided. In the closing stage of learning the teacher concludes the learning outcomes, provides a moral message and ends with greetings.

The results of observations of student activities during learning using PowerPoint media in cycle II of 10 aspects of the student interest in learning, namely: students feel happy when the teacher enters the class giving lessons totaling 43 (89.58\%), students answer questions given by the teacher totaling $43(89,58 \%)$, students do not speak for themselves when the teacher teaches 42 (87.5\%), students like the pictures displayed by Powerpoint when the teacher teaches 45 (93.75\%), students are happy if the teacher 
is $40(83.33 \%)$, students are happy if the teacher teaches using PowerPoint totaling 47 (97.91\%), students are not sleepy when the teacher is explaining lessons totaling 43 (89.58\%), students are happy when the teacher gives 40 exercises (83, 33\%), students do not play alone when the teacher teaches $39(81.25 \%)$, students ask the teacher if they cannot answer questions totaling 44 (91.66\%). These results indicate that in carrying out their activities there is 1 student who is in the moderate learning interest category, 2 students get a good category and 9 other students are included in the very good learning interest category. Based on the results of observations of student interest in learning at SD Negeri Pasi Pinang, Meureubo District, West Aceh Regency, in cycle II it has shown that there was a maximum increase in cycle II.

Based on the results of the second cycle questionnaire which has been presented in the table above, the application of the PowerPOint media to increase the interest in social studies learning in fourth grade students of SD Negeri Pasi Pinang, Meureubo District has been maximally applied, because each student has shown a very good increase in interest in learning, so that the questionnaire value is obtained. the average is 3.30 and is in the very good category, therefore, no further action is needed. In the second cycle of learning, the application of PowerPoint media has started to run very well. This can be seen in several things that were observed in the observations getting an average of $88.75 \%$ and it was included in the very good category, the results of the questionnaire on learning interest an average of 3.30 percent of the student's desire to learn. Therefore, there is no need for further action. The successes that have been achieved in cycle II are as follows: (a) students are very happy when the teacher enters the class giving social studies lessons using PowerPoint media, (b) students do not speak for themselves when learning, (c) students are able to adapt and move forward, (d) students have the courage to ask questions if they do not understand when learning social studies using PowerPoint media, (e) students are already interested in doing assignments when the teacher gives assignments.

\section{Discussion}

The results of the study are based on the results of a questionnaire followed by a reflection of observations on the action cycle. In the second cycle, it was found that the fourth grade students of SD Negeri Pasi Pinang in the social studies subject had achieved maximum results. 
Improvement of Learning Interest Through Powerpoint on the Natural Impact Materials of...

Based on the results of observations of students who can show an interest in learning in social studies learning on natural appearance material, the results achieved, namely by using PowerPoint media, students not only learn while playing, but also experience a more creative learning process, able to express opinions / ideas in solve a problem and also by using PowerPoint media students are able to know and get to know current technological developments so that students can adapt themselves to the times.

For this reason, the role of the teacher is very important in the teaching and learning process, especially in choosing learning media. PowerPoint media is an alternative learning media in this study. In making PowerPoint media, the teacher must prepare enough time and energy, be creative in adjusting the material to be taught, able to make students interested in the media displayed so that students focus their attention which can show student interest in social studies learning material appearance of nature during the process learning takes place. Student activities in cycle I and cycle II, students have been active in following the teaching and learning process well. However, in the first cycle students were new to the introduction of PowerPoint media so students were less interested and only saw the writings in PowerPoint and also students were still afraid to ask questions and move forward. In cycle II students have experienced an increase in interest in social studies learning. They have been able to adapt themselves to PowerPoint media on natural appearance material with attractive displays from before so that students focus their attention and have a high interest in fun learning.

Student interest in learning has increased from cycle I to cycle II. This can be seen from the results of the percentage of observations obtained on average $54.16 \%$ including the category of interest in learning is not good, while for the results of the questionnaire obtained an average of 2.06. Whereas in the second cycle the results of the percentage of observations obtained an average of $88.75 \%$ including the category of very good interest in learning and the results of the questionnaire an average of 3.30. In social studies learning using PowerPoint media, it was seen that the desire of students to learn on the material of students' natural appearance grade IV at SD Negeri Pasi Pinang, Meureubo District, West Aceh Regency.

\section{Conclusion}

Based on the research results, the writer can conclude that there is an increase in interest in learning through PowerPoint media. Fourth grade students of SD Negeri 
Pasi Pinang, Meureubo District, West Aceh Regency from the first cycle based on the observation results obtained an average of $54.16 \%$ while the questionnaire results obtained a score of 2.06 and in the second cycle the observation results obtained an average score of $88.75 \%$, the questionnaire results obtained a score of 3.30 . At the time of the learning process using PowerPont media, students' attention was very big in learning when the teacher explained material about natural appearances.

Based on the results of research on fourth grade students of SD Negeri Pasi Pinang, Meureubo District, West Aceh Regency, the researcher can submit the following suggestions:

1. Teachers in the learning process are expected to be able to use creative learning media (one of which is PowerPoint media) in each learning process so that students have a high interest or desire to take part in lessons. In using the media the teacher also pays attention to the conditions of students and is adjusted to the material being taught.

2. For students, with PowerPoint media it is expected that students have a high desire to take part in lessons and always focus their attention when the learning process takes place.

3. For subsequent studies, the display in PowerPoint can be further developed to make it more attractive, while still paying attention to the appearance and animation according to the students. So that the learning process, and ultimately student learning outcomes can be obtained more optimally.

\section{Bibliography}

Achmadi, Heri, dkk. 2014. Penerapan Model ASSURE dengan Menggunakan Media PowerPoint dalam Pembelajaran Bahasa Inggris Sebagai Usaha Peningkatan Motivasi dan Prestasi Belajar Siswa Kelas X MAN Sukhoharjo. Surakarta: UNS. Jurnal Teknologi Pendidikan dan Pembelajaran Vol.2, No 1, Edisi Maret 2014.

Arikunto, Suharsimi. 2016. Prosedur Penelitian. Cetakan kelimabelas. Jakarta: Rineka Cipta.

Elpira, Nira. 2015. Pengaruh Penggunaan Media Powerpoint terhadap Minat dan Hasil Belajar IPA Siswa Kelas IV SD. Yogyakarta: UNY. Jurnal Inovasi Teknologi Pendidikan Volume 2, No 1, April 2015. 
Improvement of Learning Interest Through Powerpoint on the Natural Impact Materials of...

Hitler, Ahmad. 2013. Penggunaan Media Presentase Microsoft PowerPoint UntukMeningkatkan Hasil Belajar IPS Terpadu Pada Siswa Kelas VIII ASMP Negeri 2 Tanantovea. UNTAD.

Mardhatillah, M., Verawati, V., Evianti, E., \& Pramuniati, I. (2019). Bahan Ajar Interaktif Berbasis Kearifan Lokal Melalui Pendekatan Saintifik Pada Pembelajaran Bahasa Inggris. Genta Mulia: Jurnal Ilmiah Pendidikan, 10(1).

Nisa, Ana Fitrotun. 2012. Media PowerPoint dalam Peningkatan Hasil Belajar pada Pembelajaran Sains di Kelas IV MI Ma'Had Islamy Kotagede Yogyakarta. Yogyakarta: UIN Sunan Kalijaga. Skripsi 